\title{
Four new species of Drymusa Simon (Araneae, Drymusidae) from Brazilian Oriental Amazonia
}

\author{
Alexandre B. Bonaldo ${ }^{1}$; Cristina A. Rheims ${ }^{2} \&$ Antonio D. Brescovit ${ }^{2}$ \\ 1 Departamento de Zoologia, Museu Paraense Emílio Goeldi. Avenida Magalhães Barata 376, Caixa Postal 399, \\ 66040-170 Belém, Pará, Brasil. E-mail: bonaldo@museu-goeldi.br \\ ${ }^{2}$ Laboratório de Artrópodes, Instituto Butantan. Avenida Vital Brasil 1500, 05503-900 São Paulo, São Paulo, Brasil. \\ E-mail: cris.rheims@butantan.gov.br; adbresc@terra.com.br
}

\begin{abstract}
Four new species of Drymusa Simon, 1891 are described from the Oriental Amazonia, namely: Drymusa tobyi sp. nov., D. philomatica sp. nov., D. colligata sp. nov., and D. spelunca sp. nov., all from the state of Pará, Brazil. KEY WORDS. Neotropical; taxonomy.
\end{abstract}

RESUMO. Quatro espécies novas de Drymusa Simon (Araneae, Drymusidae) da Amazônia oriental brasileira. Quatro espécies novas são descritas para a Amazônia oriental: Drymusa tobyi sp. nov., D. philomatica sp. nov., $D$. colligata sp. nov. e D. spelunca sp. nov., todas do estado do Pará, Brasil.

PALAVRAS-CHAVE. Neotropical; taxonomia.

Early in its taxonomic history, the monotypic family Drymusidae Simon, 1891 was acknowledged as a widespread taxon, with species occurring from Central America (one species) and the Caribbean (four species) to South Africa (three species) (Platnick 2005). Its occurrence in South America was recorded only recently, with the description of Drymusa serrana Goloboff \& Ramirez, 1991 from Argentina. The gap between the neotropical distribution records of Drymusa Simon, 1891 was shortened by BRESCOvit et al. (2004), who described $D$. canhemabae Brescovit, Bonaldo \& Rheims, 2004, from the Oriental Amazonia, the first Brazilian record for the family. Both South American species were known only from the types, leading BRESCOVIT et al. (2004) to suggest that these species present restricted distribution ranges and high degrees of endemism.

In this paper we deal with only eight specimens, half of which were collected during extensive sampling procedures for structured spider inventories. These few specimens nevertheless represent an unsuspected high degree of richness of Drymusa species in Brazilian Oriental Amazonia and we consider them below as belonging to four new species. Thus, the number of species known in Brazil surpasses the number currently known for the Caribbean, making the Brazilian Oriental Amazonia the richest region in the world regarding Drymusidae diversity. Considering the poor coverage of most of South America with regard to spider sampling, it seems likely that we are just starting to describe the actual species richness of northern South America drymusids.

As far as we know, the species described here match the pattern of rarity and endemicity for South American drymusids, since they are known only from their respective types and type localities. Considering the available data, all South American Drymusa species have allopatric dispersion, except for $D$. canhemabae and D. colligata sp. nov., both known from the same bauxite mining area at the Juruti River Plateau, western state of Pará. From a conservation point of view, the presence of a second Drymusa in this area supports BRESCOVIT's et al. (2004) claim on the necessity of compensatory and mitigatory measures to preserve areas adjacent to Juruti River Plateau and to minimize the impact of mining activities. Unfortunately, other species described here may also be endangered. Drymusa tobyi sp. nov. is known to occur in the Jarí Project Area, a multi-million dollar forestry enterprise in the boundary between the states of Pará and Amapá (SILVA 1991). The known distribution areas of the remaining two species lie within National Forests (FLONAs), a conservation unit category which, nonetheless, allows monitored human intervention. Drymusa spelunca sp. nov. occurs in very small caves in the middle of the largest mining plant in Brazil, within the Carajás National Forest, which houses four large mines, for iron, manganese, copper and gold. Apparently, only one species of Brazilian Drymusa is reasonably protected by now, D. philomatica sp. nov., whose distribution range lies in the Ferreira Penna Scientific Station, inside the Caxiuanã National Forest. This FLONA will remain pristine until the approval of it's environmental management plan and the area belonging to the Scientific Station (33.000 out of 330.000 ha) will probably be confirmed as restricted for research. However, a significant portion of the remaining Caxiuanã area will be destined for planned, large scaled, logging. For this reason, the development of Caxiuanã's management plan is crucial to establish the conservation status of this species. 
The material examined is deposited in the following institutions (abbreviation and curator in parenthesis): Instituto Butantan, São Paulo (IBSP, A.D. Brescovit), Museu Paraense Emílio Goeldi, Belém (MPEG, A.B. Bonaldo) and Museu de Zoologia da Universidade de São Paulo, São Paulo (MZSP, R. Pinto da Rocha). Descriptions and terminology follow BREsCovit \& RheIMs (2000) for scytodid spiders. Epigyna were dissected and immersed in clove oil to study internal structures. All measurements are given in millimeters. Micrographs were obtained with a JEOL (JSM 840A) scanning electron microscope from the "Laboratório de Microscopia Eletrônica do Departamento de Física Geral do Instituto de Física da Universidade de São Paulo (USP)".

\section{Drymusa tobyi sp. nov. Figs 1-3}

Types. Male holotype from BraziL, Pará: Almeirim (Quaruba, Monte Dourado, Genetic Reserve, 0001'32"S, 52 $54^{\prime} 17^{\prime \prime} \mathrm{W}$ ), T. Gardner leg., 28/VIII-03/IX/2004, deposited in MPEG 1705. Etymology. The specific name honors the ecologist Toby Gardner, from the University of East Anglia, Norwich Norfolk, United Kingdom, who collected this small spider in a large 35 liters bucket.

Diagnosis. The male of Drymusa tobyi sp. nov. can be distinguished from the remaining species of the genus by the bifid apex of the palpal bulb (Figs 2-3).

Description. Male (holotype). Carapace orange with brown borders and semicircular brown median pattern, as shown on figure 1. Eye borders black. Chelicerae orange. Sternum and labium brown. Endites pale orange. Legs orange. Femora with brownish venter and dorsal longitudinal brown stripe. Patellae, tibiae and metatarsi with very faint transversal brown bands. Abdomen bluish-gray with eight trasnversal brown stripes (Fig. 1). Total length 2.40. Carapace slightly flattened, 1.15 long, 1.00 wide. Eye diameters: PME 0.10, ALE 0.10, PLE 0.08. Lateral eyes on a tubercle. Chelicerae with two small retromarginal teeth, promarginal carina and subapical hyaline keel. Labium 0.24 long, 0.24 wide. Sternum 0.58 long, 0.62 wide. Leg measurements: I: femur 2.30/patella 0.30/tibia $2.46 /$ metatarsus 2.32/tarsus 0.66/total 8.04; II: 2.30/0.32/2.28/2.22/ 0.68/7.80; III: 1.80/0.34/1.60/1.72/0.58/6.04; IV: 2.20/0.34/ 2.16/2.22/0.70/7.62. Male palp with small, truncated cymbium. Bulb 0.36 long, narrow and strongly curved upwards (Figs 23). Abdomen 1.20 long, 0.60 wide, covered with slender hairs.

Female unknown.

Natural History. The holotype was collected in a pitfall trap composed by an array of four buckets (35 liters each) linked by drift fences. This array was installed in a preservation area (Quaruba Genetic Reserve) of relatively continuous primary (dry land) forest stretching eastwards through the company logging concession, which is not yet logged. The understory is dominated by palms. This site is distinct from other primary forest sites in the region by being situated on sandy soils. Thus, the canopy cover is much lower $(25-30 \mathrm{~m})$, even though there are emergent trees reaching $50 \mathrm{~m}$. The surrounding forest contains patches of naturally occurring "cerrado" (Savannah) vegetation. The area is bordered to the north by "capoeira" (secondary forest), to the west and south by further primary forest as well as plantation areas approximately $15 \mathrm{~km} \mathrm{SW}$. (T. Gardner, pers. comm.).

Distribution. Only known from the type locality.

Material examined. Only the holotype.

\section{Drymusa colligata sp. nov. Figs 4-6}

Type. Female holotype from BraziL, Pará: Juruti (Platô do Rio Juruti, Igarapé Mutum, 02³6'10,6”S, 56²12'25.8”W), 06/ XI/2002, deposited in MPEG 2169.

Etymology. The specific name is a Latin adjective meaning "together", in reference to the sympatric dispersion of $D$. canhemabae and this species.

Diagnosis. Females of Drymusa colligata sp. nov. are distinguished from other known Drymusa by the triangular plate, below the epigastric furrow and between the small and curved slerotinized ridges (Fig. 5) of the female epigynum.

Description. Male. Unknown.

Female. (holotype).Carapace orange with brown margins and median V-shaped pattern, as shown on figure 4 . Chelicerae orange. Pedipalps yellow. Labium and endites brown, distally cream colored. Sternum brown. Legs yellow. Femora and tibiae with slightly brown extremities. Abdomen dorsally bluish gray with four transversal W-shaped black stripes (Fig. 4). Ventrally brown. Total length 3.00. Carapace slightly flattened, 1.30 long, 1.10 wide. Eye diameters: PME 0.10, ALE 0.10, PLE 0.10. Lateral eyes on a tubercle. Chelicerae with two small retromarginal teeth, promarginal carina and subapical hyaline keel. Labium 0.26 long, 0.24 wide. Sternum 0.64 long, 0.68 wide. Leg measurements: I: femur 2.16/patella 0.36/tibia 2.20/ metatarsus 2.30/tarsus 0.68/total 7.70; II: 1.88/0.40/1.90/2.10/ 0.64/6.84; III: 1.52/0.34/1.46/1.54/0.64/5.50; IV: 1.88/0.36/ 2.00/2.02/0.68/6.94. Epyginum with large triangular epigynal pouch (Fig. 5). Vulva with small oval spermathecae on long stalks, arising laterally from the sclerotized ridges (Fig. 6). Abdomen 1.60 long, 1.10 wide, covered with slender hairs.

Natural History. The holotype was collected during a preliminary structured inventory carried out in a bauxite mining at Juruti River Plateau, at the same one hectare plot in which the holotype of $D$. canhemabae was collected. The single specimen of $D$. colligata sp. nov. was found in a manually sorted litter sample (one square meter of litter sorted for 20 minutes).

Distribution. Only known from the type locality.

Material examined. Only the holotype.

\section{Drymusa spelunca sp. nov.}

\section{Figs 7-9, 13-18}

Types. Female holotype from Brazil, Pará: Carajás (Gruta N5S-20, 06 $05^{\prime} 15^{\prime \prime}$ S, 5007'35"W), 3-13/V/2005, Andrade \& Arnoni leg., deposited in IBSP 51735. Paratypes: 1 female, (Gruta 


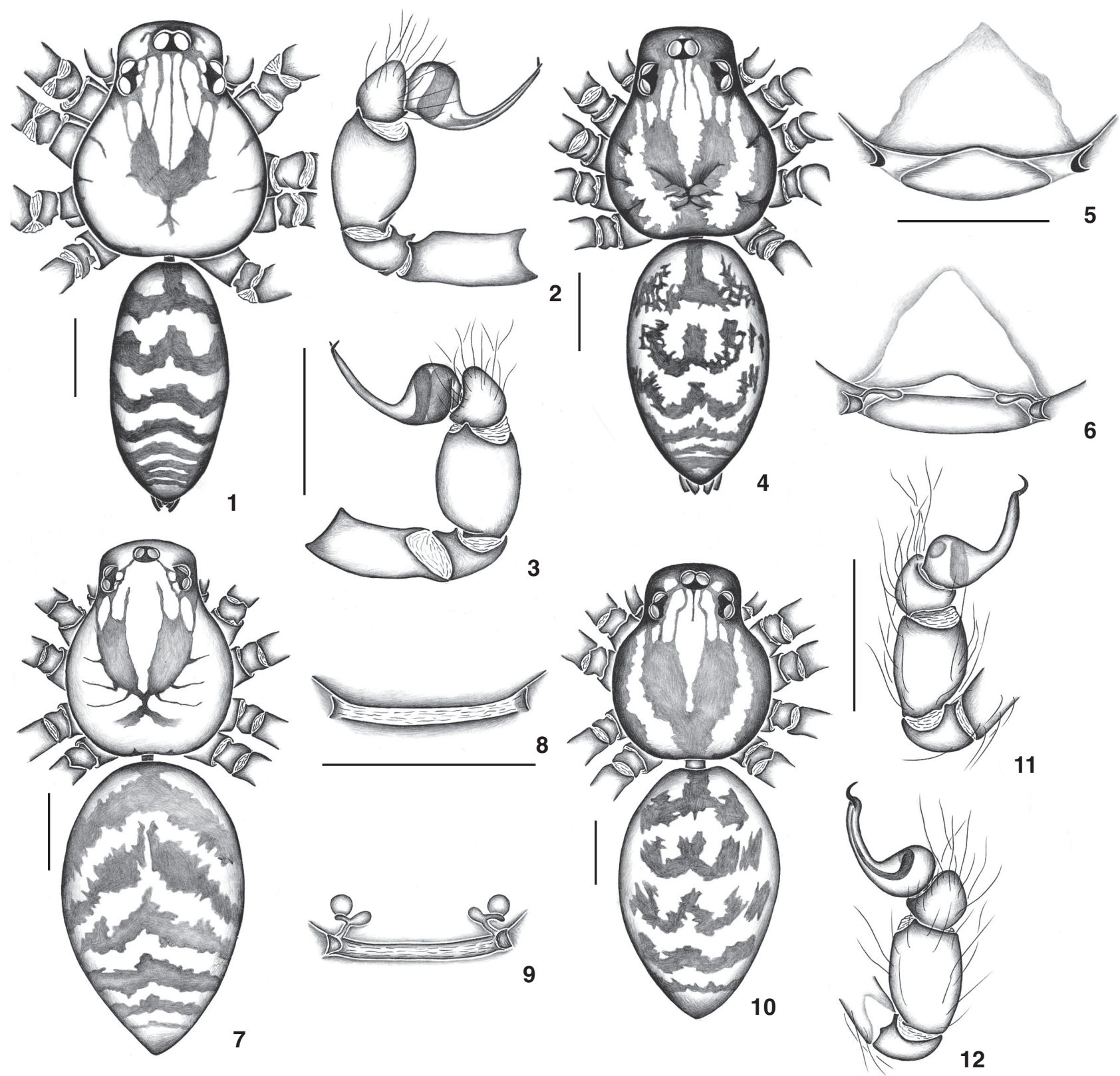

Figures 1-12. (1-3) Drymusa tobyi sp. nov.: (1) male, body, dorsal view; (2) left palp, prolateral view; (3) retrolateral view; (4-6) Drymusa colligata sp. nov.: (4) female, body, dorsal view; (5) epigynum, ventral view; (6) dorsal view; (7-9) Drymusa spelunca sp. nov.: (7) female, body, dorsal view; (8) epigynum, ventral view; (9) dorsal view; (10-12) Drymusa philomatica sp. nov.: (10) male, body, dorsal view; (11) left palp, prolateral view; (12) retrolateral view. Scale bars: $0.5 \mathrm{~mm}$.

N5S-13, 06 $\left.06^{\prime} 19^{\prime \prime} \mathrm{S}, 50^{\circ} 08^{\prime} 01^{\prime \prime} \mathrm{W}\right)$ (MZSP 24996); 1 female (Gruta N5S-07, 06 $06^{\prime} 20^{\prime \prime} \mathrm{S}, 50^{\circ} 07^{\prime} 59^{\prime \prime} \mathrm{W}$ ) (MPEG 2217); 1 fe-

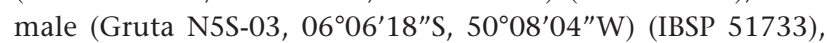
all with same data as holotype.

Etymology. The specific name is a Latin noun that means cave, in reference to the habitat in which all specimens of this species were collected.

Diagnosis. Females of Drymusa spelunca sp. nov. are distinguished from other known Drymusa by the vulva with pair of spermathecae, one round with inconspicuous stalk and one oval on long and slender stalk (Fig. 9).

Description. Male. Unknown.

Revista Brasileira de Zoologia 23 (2): 455-459, junho 2006 

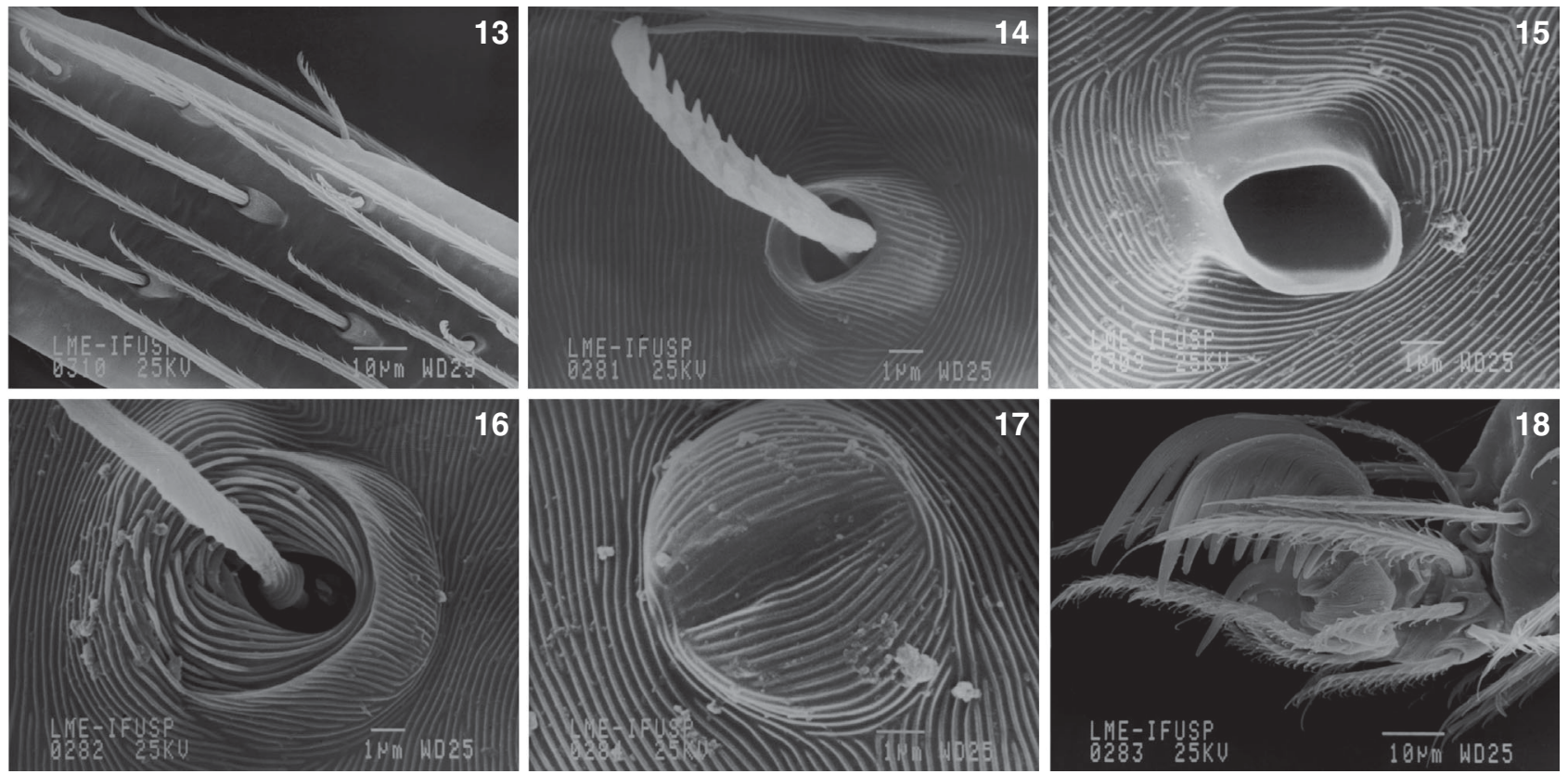

Figures 13-18. Drymusa spelunca sp. nov.: (13) tíbia I, long serrated setae and sparce short modified hairs with inflated base; (14) modified hairs, detail; (15) Leg I, femur, probable sensory structure, dorsal view; (16) metatarsi I, trichobothria, dorsal view; (17) tibia I, round, slit sensilla, dorsal view; (18) tarsi I, claws on conspicuous onychium, prolateral view.

Female. (IBSP 51733). Carapace yellow with light brown median V-shaped pattern, as shown on figure 7. Chelicerae pale orange. Sternum, labium and endites yellow. Legs and pedipalps pale orange. Abdomen bluish gray with 6 transversal black stripes (Fig. 7). Total length 2.50. Carapace slightly flattened, 1.15 long, 0.70 wide. Eye diameters: PME 0.06, ALE 0.06, PLE 0.06. Lateral eyes on a tubercle. Chelicerae with two small retromarginal teeth, promarginal carina and subapical hyaline keel. Labium 0.20 long, 0.16 wide. Sternum 0.58 long, 0.54 wide. Leg measurements: I - femur 1.42/patella 0.30/tibia 1.50/ metatarsus 1.36/tarsus 0.56/total 5.14; II - 1.40/0.28/1.20/1.24/ 0.50/4.62; III - 1.10/0.28/0.94/1.02/0.42/3.76; IV - 1.42/0.30/ $1.36 / 1.30 / 0.54 / 4.92$. Legs covered by long serrated setae and sparce short modified hairs with inflated base (Figs 13-14). Probable dorsal sensory structure smooth, oval and projected (Fig. 15) on femur. Trichobothria with single large rugose transverse plate and long bothrium dorsally on metatarsus I (Fig. 16). Slit sensilla round and rugose on metatarsus I (Fig. 17). Tarsi with three claws, paired claws with 6-7 teeth each, and unpaired claw unarmed, on conspicuous onychium (Fig. 18). Epyginum with inconspicuous epigynal pouch and small, curved, sclerotized lateral ridges (Fig. 8). Abdomen 1.15 long, 0.70 covered with slender hairs.

Variation. Four females. Total length: 2.50-3.00; carapace: 1.15-1.20; femur I: 1.42-1.60.

Natural History. This species was collected during the day, under rocks, in very small caves (no larger than $20 \mathrm{~m}$ ). These caves are located on the hillside of small plateaus, in a transition area between Amazonian Forest vegetation and "Canga" (R. Andrade, pers. comm.). The latter refers to small areas of open vegetation that occur around waterfilled depressions in outcrops of iron ore (Morellato \& Rosa 1991). The area lies within the Floresta Nacional de Carajás (FLONA), which houses four large mines, for iron, manganese, copper and gold, all administered by the Companhia do Vale do Rio Doce.

Distribution. Only known from the type locality.

Material examined. Only the types.

\section{Drymusa philomatica sp. nov.}

\section{Figs 10-12}

Types. Male holotype from Brazil, Pará: Melgaço, (Estação Científica Ferreira Penna, Floresta Nacional de Caxiuanã,

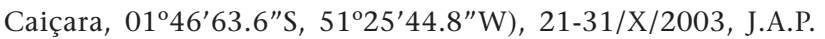
Barreiros et al. leg., deposited in MPEG 2172. Paratype: 1 male, with the same data as holotype (IBSP 51736).

Etymology. The specific name refers to the Philomatic Association (friends of science), founded by Domingos Soares Ferreira Penna in 1866, which became the seed of the Goeldi Museum.

Diagnosis. Males of Drymusa philomatica sp. nov. are easily distinguished from the remaining Drymusa by the apex of the embolus abruptly narrowed and hook-shaped (Figs 11-12).

Description. Male (holotype). Carapace orange with wide brown margins and median $\mathrm{V}$-shaped pattern, as shown on

Revista Brasileira de Zoologia 23 (2): 455-459, junho 2006 
figure 10. Chelicerae orange with dorsal, longitudinal brown stripe. Pedipalps orange with very slight irregular brown markings. Labium and endites brown, distally cream colored. Sternum brown, slightly darker at margins. Legs orange with transversal brown bands, except on tarsi. Abdomen dorsally cream colored with three transversal W-shaped stripes on anterior half and three transversal straight stripes on posterior half (Fig. 10). Ventrally cream colored with three very wide transversal brown stripes. Total length 2.30. Carapace slightly flattened, 1.10 long, 0.90 wide. Eye diameters: PME 0.08, ALE 0.10, PLE 0.10. Lateral eyes on a tubercle. Chelicerae with two small retromarginal teeth, promarginal carina and subapical hyaline keel. Labium 0.28 long, 0.20 wide. Sternum 0.56 long, 0.60 wide. Leg measurements: I: femur $1.86 /$ patella $0.30 /$ tibia $1.96 /$ metatarsus $1.96 /$ tarsus $0.66 /$ total 6.74 ; II: $1.80 / 0.30 / 1.84 / 1.84 / 0.64 / 6.42$; III: 1.44/0.20/1.30/1.44/0.58/4.96; IV: 1.14/0.20/1.12/1.22/0.44/ 4.12. Male palp with small, truncated cymbium. Bulb 0.40 long, narrow and strongly curved upwards (Figs 11-12). Abdomen 1.20 long, 0.70 wide, covered with slender hairs.

Female. Unknown.

Variation. Two males. Total length: 2.30-2.40; carapace: 1.00-1.10; femur I: 1.86-1.90.

Natural History. Both known specimens were collected in a 1 hectare plot established for a multi-taxonomic structured inventory (IMC Project) at Caiçara, an area which represents the transition from wetland forest (Várzea) to dry land forest (Terra Firme). The plot is situated on sandy soils, its understory is dominated by palms and is open when compared to other areas in the Scientific Station. The canopy is low (less than 25 meters high). These features make this site somewhat similar to that in which $D$. tobyi sp. nov. was found in Monte Dourado. Nevertheless, the Caiçara site is located near the Caxiuanã Bay and for this reason bears tide influence. The two specimens were collected in two of 25 pitfall traps, made out of plastic cups with 10 centimeters aperture diameter and 500 milliliters capacity, during the dry season. No additional individuals were collected with Winkler apparatus (20 samples of one square meter of litter each) or with litter manual sorting (10 samples of one square meter of litter each). An identical sampling effort during the wet season failed to sample any drymusids (J.A.P. Barreiros, pers. comm.).

Distribution. Only known from the type locality.
Material examined. Only the types.

\section{ACKNOWLEDGEMENTS}

We wish to thank Bernhard Huber, Abel P. González, Sidclay C. Dias, Arno A. Lise and Toby Gardner for helpful comments on this manuscript; Renata Andrade (IB/USP), J.A.P Barreiros (MPEG), and Toby Gardner for collecting some of the specimens; and Pedro Kyohara and Simone Perche Toledo (Laboratório de Microscopia Eletrônica, Instituto de Física, Universidade de São Paulo) for making the electron scanning micrographs. This study was supported by Conselho Nacional de Pesquisa e Desenvolvimento Tecnológico (CNPq - PQ, ABB and $\mathrm{ADB}$ ) and Fundação de Amparo à Pesquisa do Estado de São Paulo (FAPESP 99/05446-8; 02/11277-9). This work is part of BIOTA/FAPESP - The Biodiversity Virtual Institute Program (www.biotasp.org.br). The support in the Ferreira Penna Scientific Station was provided by Multi-taxonomic Inventory of Caxiuanã National Forest (PNOPG/CNPq).

\section{REFERENCES}

Brescovit, A.D. \& C.A. Rherms. 2000. On the synanthropic species of the genus Scytodes Latreille (Araneae, Scytodidae) of Brazil, with synonymies and records of these species in other Neotropical countries. Bulletin of the British Arachnological Society, Dorset, 11: 320-330.

Brescovit, A.D.; A.B. Bonaldo \& C.A. Rheims. 2004. A new species of Drymusa (Araneae, Drymusidae) from Brazil. Zootaxa. Auckland, 697: 1-5.

Goloboff, P.A. \& M.J. Ramírez. 1991. A new species of Drymusa (Araneae: Scytodidae) from Argentina. Journal of the New York Entomological Society, New York, 99: 691-695.

Morellato, L.P.C. \& N.A. Rosa. 1991. Caracterização de alguns tipos de vegetação na região Amazônica, Serra dos Carajás, Pará, Brasil. Revista Brasileira de Botânica, São Paulo, 14: $1-14$.

Platnick, N. I. 2005. The world spider catalog, version 5.5. American Museum of Natural History. On line at: http:// research.amnh.org/entomology/spiders/catalog/index.html [Accessed in 29/XI/2005]

SILVA, S. 1991. Projeto Jari - a invasão americana. São Paulo, Ed. Brasil, Debates, 110p.

Received in 17.VIII.2005; accepted in 04.V.2006. 